\title{
FAKTOR-FAKTOR YANG MEMENGARUHI CAPAIAN LITERASI MATEMATIKA SISWA INDONESIA DALAM PISA 2012
}

\section{FACTORS AFFECTING LITERACY MATHEMATICS ACHIEVEMENT OF INDONESIAN STUDENT IN PISA 2012}

\author{
Rogers Pakpahan \\ Pusat Penilaian Pendidikan, Balitbang, Kemendikbud \\ Jalan Gunung Sahari Raya No 4 Jakarta \\ e-mail: ropakpakro@yahoo.com
}

Naskah diterima tanggal: 17-12-2016, Direvisi akhir tanggal: 29-12-2016, disetujui tanggal: 30-12-2016

\begin{abstract}
In order to obtain information on the quality of education and the system education that are underway in various countries, it is conducted international studies called Programme for International Student Assessment (PISA). This study aims to determine the factors that affect student background of literacy mathematics achievement by PISA 2012. The study population was 15 years old Indonesian student. Samples were 5622 students of 15 year old students spread across 31 provinces. The sampling and data collection is determined by PISA in 2012 with a random sampling conducted by multilevel, clustering, and stratified. PISA data collection instruments consist of test capabilities (learning achievement) and questionnaires. The results showed that the factors that affect literacy mathematics achievement of PISA 2012 are the background from internal factors such as the personal character (discipline) of the student and external factors such as the condition of the family, ownerships of the means of learning, and social and cultural conditions at home. The study concluded that character, socio-economic and cultural conditions, computer ownership, and text book are the main factors that affect Indonesian students' mathematics literacy achievement of PISA 2012.
\end{abstract}

Keywords: mathematics literacy, students' acheivement, PISA, Indonesian students

\begin{abstract}
Abstrak: Kajian ini bertujuan untuk mengetahui faktor-faktor latar belakang yang memengaruhi capaian literasi Matematika siswa Indonesia yang menjadi peserta studi PISA 2012. Populasi penelitian adalah siswa Indonesia yang berusia 15 tahun. Sampel penelitian yakni siswa berusia 15 tahun sebanyak 5.622 orang yang tersebar di 31 provinsi. Penentuan sampel dan pengambilan data ditentukan oleh PISA tahun 2012, dengan teknik random sampling yang dilakukan dengan cara multilevel, clustering, dan stratified. Hasil penelitian menunjukkan bahwa faktor-faktor yang memengaruhi prestasi siswa Indonesia pada studi PISA 2012 yaitu latar belakang peserta dari faktor internal yaitu jati diri siswa dan faktor eksternal yaitu kondisi keluarga, kepemilikan sarana belajar, dan kondisi sosial budaya di rumah. Penelitian menyimpulkan bahwa jati diri, kondisi sosial ekonomi dan budaya, kepemilikan komputer, dan buku-buku merupakan faktor utama yang memengaruhi capaian literasi matematika siswa Indonesia peserta PISA 2012.
\end{abstract}

Kata kunci: literasi matematika, prestasi siswa, PISA, siswa Indonesia 


\section{PENDAHULUAN}

Bangsa Indonesia berperan serta dalam program pembangunan berkelanjutan (sustainable development) sebagai program Millennium Development Goals (MDGs) untuk memerangi masalah besar yang dihadapi bangsa-bangsa di dunia, yaitu kemiskinan dan kebodohan (Tilaar, 2015). Pendidikan sebagai upaya untuk mencerdaskan kehidupan bangsa diharapkan dapat mengatasi kedua permasalahan tersebut. Dalam rangka untuk memeroleh informasi yang akurat mengenai mutu pendidikan dan sistem pendidikan yang berlangsung di berbagai negara dilakukan studi internasional yang dikenal dengan Programme Student for International Assessment atau PISA. Anggota PISA adalah negara-negara yang tergabung dalam OECD (Organisation for Economic Cooperation and Development) yang berkedudukan di Paris, Prancis. Anggota OECD terdiri atas 34 negara. Pada tahun 2012 terdapat 31 negara mitra yang berpartisipasi dalam studi PISA 2012 (OECD, 2013a) dan Indonesia merupakan salah satu dari negara mitra dalam studi PISA.

Studi PISA merupakan studi untuk mengetahui pengetahuan yang penting dikuasai warga negara dan keterampilan yang dapat dilakukan (OECD, 2013a). PISA bertujuan mengukur sejauh mana pendidikan dasar di suatu negara mampu menyiapkan siswa (warga negara) untuk menghadapi dunia nyata, menggapai pengetahuan yang lebih tinggi, bersosialisasi di kancah global, dan untuk memenuhi kebutuhan dasar. PISA bukan untuk mengukur kemampuan siswa dalam menguasai materi dalam kurikulum sekolah, melainkan untuk mengukur kompetensi siswa usia 15 tahun dalam beberapa pengetahuan dan keterampilan yang diperlukan untuk berpartisipasi dalam masyarakat yang difokuskan pada kompetensi membaca, matematika, dan sains. Kompetensi yang diukur meliputi kemampuan merefleksikan pengetahuan dan pengalaman mereka serta mengaplikasikannya dalam kehidupan nyata. Penekanannya pada penguasaan proses, pemahaman konsep, dan kemampuan memanfaatkan pengetahuan dalam berbagai situasi di setiap bidang yang diujikan. Informasi dari hasil PISA dapat dimanfaatkan sebagai referensi tentang seberapa baik output pendidikan dasar di suatu negara, sebagai dasar perumusan kebijakan dalam peningkatan mutu pendidikan, khususnya dalam menentukan batas bawah (treshhold) dan batas ambang ideal (bencmark) kemampuan dasar membaca, matematika, dan sains di akhir usia wajib belajar 9 tahun. Hasil capaian studi PISA menggambarkan efektivitas sistem pendidikan suatu negara dengan perspektif internasional.

Studi PISA dilakukan dengan siklus tiga tahun dengan fokus penilaian utama yang berbeda antara literasi membaca, literasi matematika, dan literasi sains. Studi PISA pertama kali dilakukan pada tahun 2000 di 32 negara dengan fokus penilaian utama tentang literasi membaca, ditambah literasi matematika dan literasi sains seperti tampak dalam Tabel 1. PISA tahun 2003 dilaksanakan di 41 negara dengan fokus penilaian utama tentang literasi matematika, ditambah literasi membaca dan sains. PISA tahun 2006 diikuti oleh 41 negara dengan fokus penilaian utama tentang literasi sains, ditambah literasi matematika dan membaca. PISA tahun 2009 diikuti oleh 65 negara dengan fokus penilaian utama tentang literasi membaca, ditambah literasi matematika dan literasi sains. PISA tahun 2012 diikuti oleh 65 negara, dengan fokus penilaian utama literasi matematika, ditambah literasi membaca dan sains. Hasil studi PISA dan posisi Indonesia sejak tahun 2000 2012 tampak pada Tabel 1.

Pada Tabel 1 tampak posisi rata-rata prestasi siswa Indonesia tergolong rendah dibandingkan dengan negara peserta studi. Perkembangan kemajuan prestasi siswa Indonesia pada penilaian utama tahun 2000 dengan fokus membaca menempati urutan 39 dari 41 negara peserta. Dibandingkan dengan prestasi tahun 2009, terjadi sedikit peningkatan menjadi urutan 48 dari 56 negara peserta. Tahun 2003 dengan fokus matematika menempati urutan 39 dari 40 negara peserta sedangkan tahun 2009 sedikit meningkat menjadi urutan 
58 dari 65 negara peserta. Tahun 2006 dengan fokus sains menempati urutan 48 dari 56 negara peserta. Perkembangan prestasi (literasi) Indonesia sejak mengikuti studi PISA tampak pada Gambar 1.

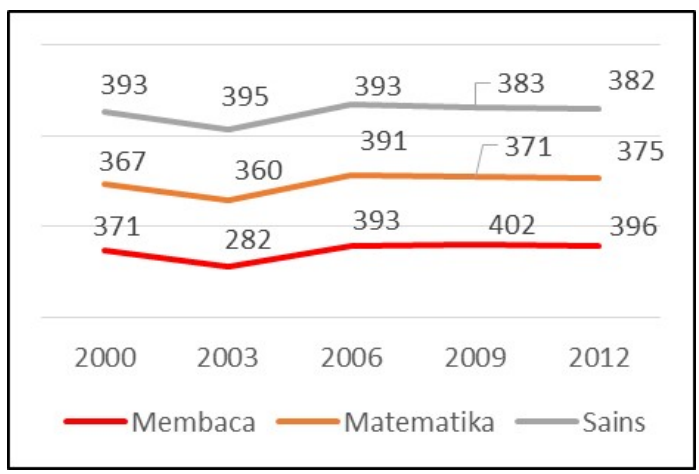

Gambar 1. Perkembangan Literasi Siswa Indonesia Tahun $2000-2012$

Pada Gambar 1 tampak perkembangan kemampuan membaca menurun pada tahun 2003 kemudian meningkat pada tahun 2006 dan selanjutnya berkembang secara monoton atau mendatar. Kemampuan Matematika cenderung naik turun secara tidak signifikan. Kompetensi sains berkembang secara merata atau stagnan. Peningkatan literasi siswa kurang menggembirakan atau tidak terjadi peningkatan dan nilai tersebut masih jauh dari nilai tertinggi di atas 600, sebagaimana terlihat pada Tabel 1.

Hasil studi PISA dikelompokkan dalam enam level (benchmark) dengan deskripsi yang berbeda-beda antardomain studi. Secara statistik nilai rata-rata negara OECD berdasarkan PISA 2012 menunjukkan nilai rata-rata matematika 494 sedangkan capaian Indonesia 375 yang tidak berbeda dengan Qatar dan Kolombia (376), ataupun Peru (368) di urutan terbawah. Untuk sains, nilai rata-rata 501, sedangkan capaian Indonesia 382 tidak berbeda secara signifikan dengan Qatar (384) dan Peru (372) di urutan terbawah. Posisi Indonesia pada benchmark literasi matematika pada level dua, literasi sains pada level dua, dan literasi membaca level tiga (OECD, 2013a). Capaian tersebut sangat rendah dibandingkan pada level tertinggi yaitu level enam.
Berdasarkan uraian tersebut, penelitian ini berupaya untuk mengetahui faktor-faktor apakah yang memengaruhi capaian literasi matematika siswa peserta studi PISA 2012 sehingga termasuk pada kategori rendah atau hanya berada pada level dua. Pertanyaan penelitian adalah 1) Adakah faktor jati diri siswa Indonesia peserta Studi PISA 2012 memengaruhi capaian literasi Matematika? 2) Apakah faktor lingkungan sosial budaya siswa Indonesia peserta PISA 2012 memengaruhi capaian literasi Matematika? 3) Apakah ada faktor dominan yang memengaruhi capaian literasi Matematika siswa Indonesia peserta PISA 2012? Ruang lingkup pembahasan yaitu faktor jati diri atau latar belakang, lingkungan sosial budaya, dan kepemilikan sarana belajar yang memengaruhi capaian literasi Matematika siswa peserta PISA 2012. Namun demikian, untuk mendapatkan gambaran (pembanding) yang lebih luas, disertakan data capaian literasi Matematika peserta negara lain sesuai dengan topik yang dibahas.

Penelitian ini bertujuan untuk 1) mendapatkan gambaran tentang jati diri siswa Indonesia peserta PISA 2012 yang memengaruhi capaian literasi matematika, 2) mengetahui faktor lingkungan sosial budaya yang memengaruhi capaian literasi matematika siswa Indonesia peserta PISA 2012, dan 3) faktor dominan yang memengaruhi capaian literasi matematika siswa Indonesia peserta PISA 2012. Hasil penelitian ini diharapkan dapat membantu pengambil kebijakan untuk memahami faktor-faktor yang memengaruhi capaian literasi matematika siswa Indonesia peserta PISA 2012, dan digunakan sebagai bahan perbaikan pembelajaran matematika.

Pendidikan merupakan komponen utama untuk memajukan kehidupan suatu bangsa. Bangsa dengan hasil pendidikan yang baik atau tinggi dapat meningkatkan kesejahteraannya melalui pelaksanaan pembangunan. Oleh karena itu, pendidikan merupakan investasi masa depan suatu bangsa sehingga bangsa di dunia berupaya untuk memperbaiki sistem pendidikan. 
Tabel 1. Data Hasil Survei PISA Tahun 2000-2012

\begin{tabular}{cccccc}
\hline Domain & $\begin{array}{c}\text { Tahun 2000 } \\
\text { Fokus } \\
\text { Memcaca }\end{array}$ & $\begin{array}{c}\text { Tahun 2003 } \\
\text { Fokus } \\
\text { Matematika }\end{array}$ & $\begin{array}{c}\text { Tahun 2006 } \\
\text { Fokus } \\
\text { Sains }\end{array}$ & $\begin{array}{c}\text { Tahun 2009 } \\
\text { Fokus } \\
\text { Membaca }\end{array}$ & $\begin{array}{c}\text { Tahun 2012 } \\
\text { Fokus } \\
\text { Matematika }\end{array}$ \\
\hline Membaca & $371(39 / 41)$ & $282(39 / 40)$ & $393(48 / 56)$ & $402(48 / 56)$ & $396(58 / 65)$ \\
Matematika & $367(39 / 41)$ & $360(38 / 40)$ & $391(50 / 57)$ & $371(61 / 65)$ & $375(64 / 65)$ \\
Sains & $393(38 / 41)$ & $395(38 / 40)$ & $393(50 / 57)$ & $383(60 / 65)$ & $382(64 / 65)$ \\
\hline
\end{tabular}

Sumber: OECD (2013a)

Hasil pendidikan dapat mempercepat dan menjamin proses peningkatan kemampuan pembangunan secara terus-menerus. Pendidikan merupakan suatu kebutuhan yang diperlukan suatu bangsa untuk meningkatkan kesejahteraan penduduk. Pendidikan dan pembangunan merupakan dua hal atau faktor yang saling berkaitan dalam proses pemenuhan kebutuhan kesejahteraan suatu bangsa. Ukuran keberhasilan pendidikan dapat mengacu pada indikator pembangunan atau indikator pembangunan juga dijadikan sebagai ukuran keberhasilan pendidikan di suatu bangsa.

Pendidikan merupakan usaha sadar dan terencana sehingga diperlukan suasana belajar dan proses pembelajaran yang aktif dalam pengembangan potensi peserta didik agar memiliki kekuatan spiritual keagamaan, pengendalian diri, kepribadian, kecerdasan, ahlak mulia, dan keterampilan yang diperlukan baik untuk dirinya, masyarakat, maupun bangsa dan negara (Triwiyanto, 2014). Pendidikan terjadi dalam interaksi antara peserta didik dengan pendidik dalam proses pembelajaran di ruang kelas atau di luar kelas untuk mencapai tujuan pendidikan yang meliputi aspek pengetahuan, keterampilan, dan sikap. Dalam proses pembelajaran digunakan berbagai sumber daya pendidikan untuk mencapai tujuan pembelajaran sebagai hasil yang diinginkan dan perilaku atau kompetensi peserta didik (Fathurrohman, 2015). Agar hasil pendidikan berkualitas, pemerintah telah menetapkan standar pendidikan nasional yang berfungsi untuk 1) mengukur kualitas pendidikan, 2) pemetaan masalah pendidikan,
3) penyusunan strategi dan rencana pengembangan sesudah diperoleh data dari evaluasi belajar (Raharjo, 2014). Kualitas pendidikan juga dipengaruhi oleh kemampuan satuan pendidikan dalam mengelola proses pembelajaran (Nurdin \& Adriantoni, 2016). Hasil pembelajaran ini menciptakan aspek pengetahuan atau kemampuan atau keterampilan peserta didik yang disebut capaian belajar.

Peserta didik atau warga negara yang berusia 15 tahun dapat memeroleh pengetahuan atau keterampilan yang dibutuhkan dalam kehidupan melalui pembelajaran di satuan pendidikan atau pengalaman peserta didik dalam dunia nyata yang ada di lingkungan tempat tinggalnya. Pengetahuan atau keterampilan yang dimiliki warga negara dari satuan pendidikan dan lingkungan digunakan untuk meningkatkan kesejahteraannya. Dengan demikian, capaian belajar merupakan kemampuan atau keterampilan yang dimiliki warga negara (peserta didik) dari proses pembelajaran di satuan pendidikan dan dari masyarakat sesuai pengalaman dalam proses interaksinya pada kehidupan sehari-hari.

Untuk mengetahui capaian belajar aspek pengetahuan dan keterampilan dilakukan penilaian dengan menggunakan berbagai instrumen penilaian tertulis berupa tes, observasi, penugasan, projek, dan produk. Bentuk penilaian tersebut digunakan oleh pendidik untuk memeroleh capaian aspek pengetahuan dan keterampilan secara menyeluruh. Dalam pelaksanaan penilaian, bentuk penilaian tersebut saling melengkap atau komplementer satu dengan lainnya walaupun 
dalam prakteknya para pendidik lebih mengutamakan penilaian tertulis (Panjaitan, 2014). Melalui peggunaan berbagai bentuk penilaian diperoleh pengetahuan dan keterampilan peserta didik secara utuh. Penilaian internal merupakan penilaian hasil belajar yang dilakukan oleh pendidik atau satuan pendidikan selama proses pembelajaran berlangsung seba-gai penjaminan mutu dan penilaian eksternal merupakan penilaian yang dilakukan pihak luar dari satuan pendidikan sebagai pengelola pembelajaran, seperti ujian nasional sebagai pengendali mutu nasional dan pemetaan mutu pendidikan (Pakpahan, 2012). Contoh penilaian eksternal lainnya adalah Studi PISA yang diselenggarakan oleh pihak di luar satuan pendidikan untuk memeroleh informasi keterampilan yang diperlukan siswa dalam kehidupannya.

Studi PISA merupakan program negara OECD yang melakukan penilaian internasional untuk mengukur kemampuan atau literasi membaca, literasi matematika, dan literasi sains pada siswa berusia 15 tahun. Dalam sistem pendidikan nasional, siswa dengan usia tersebut duduk di kelas 3 SMP/MTs dan kelas 1 SMA/SMK/MA. Namun demikian, penilaian ini tidak berkaitan atau menilai capaian siswa sesuai dengan kurikulum pendidikan. Studi PISA dilakukan setiap tiga tahun dengan fokus penilaian atau disebut main survey yang berbeda. Pada awalnya studi PISA dilaksanakan tahun 2000, seperti tampak dalam Tabel 1 dengan siklus fokus atau penilaian utama antara literasi membaca, dan literasi matematika, literasi sains sebagai pelengkap. Jumlah negara peserta studi PISA yang awalnya 41 negara menjadi 65 negara tahun 2012. Penilaian utama PISA 2012 yaitu literasi matematika, dan sebagai pelengkap materi literasi membaca dan literasi sains.

Literasi diartikan sebagai kemampuan membaca dan mengolah informasi saat (proses) membaca atau menulis. Literasi merupakan suatu kebutuhan yang diperlukan manusia sebagai dasar untuk belajar sepanjang hayat, yang mencakup berbagai aspek kehidupan
(Mahdiansyah \& Rahmawati 2014). Literasi berkembang menjadi konsep fungsional yang berkaitan dengan berbagai fungsi dan keterampilan hidup. Literasi matematika adalah kemampuan individu untuk merumuskan, menerapkan, dan menafsirkan matematika dalam berbagai konteks kehidupan. Kemampuan meliputi penalaran matematis dan penerapan konsep matematika, prosedur, fakta dan alatalat untuk menggambarkan, menjelaskan, dan memprediksi fenomena. Kemampuan tersebut membantu individu untuk mengakui peranan matematika di dunia dan membuat penilaian dalam pengambilan keputusan konstruktif, terkait dan refleksi warga (OECD, 2013b). Kemampuan matematika sangat diperlukan dalam berbagai aspek kehidupan (Darlington \& Jessica 2016) untuk membentuk pola pikir dalam beradaptasi dengan perkembangan ilmu pengetahuan dan teknologi.

Berbagai penelitian yang menggunakan data PISA antara lain Willms (2011), mengkaji hasil penilaian PISA untuk perbaikan penampilan sekolah, guru, dan aspek atau topik yang dinilai dalam PISA. Ozga (2012), membahas upaya memperbaiki proses penilaian yang dilakukan oleh PISA. Sementara itu, Sellar \& Bob (2014), menyimpulkan urgensi kerja sama pendidikan dalam OECD dalam konteks simultan penghematan kebijakan pendidikan berkaitan dengan kebijakan ekonomi, serta menampilkan data kinerja sekolah komparatif sebagai ukuran pengganti daya saing ekonomi global. Dalam berbagai kajian yang dilakukan, para ahli menelaah hasil-hasil PISA untuk dapat mengubah atau meningkatkan mutu pendidikan di suatu negara. Penelitian ini juga menggunakan data PISA 2012 untuk mengkaji faktor-faktor yang memengaruhi literasi siswa Indonesia peserta PISA 2012.

Capaian literasi matematika siswa peserta studi PISA merupakan hasil dari berbagai faktor yang saling terkait antara yang dipelajari di satuan pendidikan dengan pengalamannya dalam kehidupan sehari-hari. Slameto (2010) menyatakan faktor-faktor yang mempengaruhi 
prestasi belajar siswa dibagi dalam faktor internal dan faktor eksternal. Faktor internal merupakan faktor pendorong yang bersumber dari dalam diri siswa seperti faktor biologis dan faktor psikologis. Sedangkan faktor eksternal merupakan faktor yang bersumber dari luar diri siswa seperti manusia (keluarga, sekolah, masyarakat), faktor lingkungan, dan kondisi sosial ekonomi keluarga.

Sejalan dengan Slameto maka dalam penelitian ini faktor-faktor yang memengaruhi prestasi peserta studi PISA yang diambil dari kuesioner siswa dikelompokkan dalam faktor internal dan eksternal. Penelitian yang berkaitan dengan hasil belajar atau prestasi belajar dilakukan oleh Mahdiansyah \& Rahmawati (2014) yang menyimpulkan bahwa faktor yang memengaruhi capaian literasi matematika adalah faktor personal, faktor instruksional, dan faktor lingkungan. Penelitian ini menggunakan data PISA dalam konteks Indonesia. Prestasi belajar Matematika dipengaruhi oleh penerapan umpan balik dalam proses pembelajaran meningkatkan kemampuan peserta didik (Paneo, 2004). Dalam setiap penilaian capaian matematika selalu diikuti dengan pemberian umpan balik atau penjelasan mengapa siswa mendapat nilai rendah atau tinggi pada topik tertentu sehingga siswa dapat menyikapi capaian tersebut. Rahman (2008) menyimpulkan faktor kemandirian belajar dapat meningkatkan prestasi belajar peserta didik. Kedua penelitian terakhir lebih khusus untuk mendeskripsikan peningkatan hasil belajar pada penekanan umpan dan faktor kemandirian dalam proses pembelajaran. Fahmi (2011) menunjukkan prestasi belajar atau rata-rata nilai akhir siswa peserta ujian nasional matematika 8,07 relatif sama dengan nilai ujian sekolah 8,13 sementara hasil studi PISA 2012 Indonesia menduduki level 2 kategori rendah.

Penelitian ini lebih khusus mengkaji faktor jati diri atau latar belakang siswa, lingkungan sosial budaya, dan kepemilikan sarana belajar yang memengaruhi capaian literasi siswa Indonesia peserta PISA 2012.

\section{METODE}

Populasi dari studi PISA adalah siswa yang berusia 15 tahun atau siswa diperkirakan siswa yang sudah menyelesaikan pendidikan wajib belajar dan sebelum menjadi dewasa yang harus menghadapi kehidupan. Siswa tersebut diperkirakan duduk di kelas 3 SMP/MTs dan kelas 1 SMA/SMK/MA yang tersebar di seluruh wilayah Indonesia. Negara peserta studi PISA harus menyerahkan daftar siswa dan sekolah yang ada di suatu negara agar pengelola PISA di Prancis dapat menentukan sampel penelitian.

Sampel penelitian terdiri atas siswa Indonesia berusia 15 tahun sebanyak 5.622 orang yang tersebar di 210 sekolah (SMP, MTs, SMA, MA, dan SMK). Sekolah tersebar di 31 provinsi yaitu DKI Jakarta, Jawa Barat, Banten, Jawa Tengah, DI Yogyakarta, Jawa Timur, Aceh, Sumatera Utara, Sumatera Barat, Riau, Kepulauan Riau, Jambi, Sumatera Selatan, Lampung, Bengkulu, Bangka Belitung, Kalimantan Barat, Kalimantan Tengah, Kalimantan Selatan, Kalimantan Timur, Sulawesi Utara, Sulawesi Tengah, Sulawesi Selatan, Sulawesi Tenggara, Sulawesi Barat, Gorontalo, Maluku, Maluku Utara, Bali, Nusa Tenggara Barat, dan Nusa Tengara Timur

Teknik dan prosedur penentuan sampel dan pengambilan data dapat dilihat pada laporan teknis PISA tahun 2012. Teknik penentuan sampel dengan random sampling dengan multilevel, clustering, dan stratified. Hal tersebut dilakukan mengingat heterogenitas negara peserta PISA dari segi jumlah penduduk, siswa, jumlah sekolah, dan sarana pendidikan. Teknik analisis digunakan analisis deskriptif untuk memeroleh gambaran jati diri atau latar belakang, lingkungan sosial budaya, dan kepemilikan sarana belajar yang memengaruhi capaian literasi siswa dan statistik inferensial untuk melihat hubungan (korelasi) antara faktor lingkungan sosial budaya dan kepemilikan sarana belajar yang memengaruhi prestasi literasi matematika siswa Indonesia peserta PISA 2012.

Instrumen pengumpulan data PISA terdiri dari dua bentuk yaitu tes kemampuan (prestasi 
belajar) dan kuesioner (OECD, 2013b). Konten tes kemampuan meliputi: space and shape (7 butir), change and relationship (11 butir), data and uncertainty (15 butir), serta quantity ( 7 butir). Bentuk soal disajikan dalam bentuk pilihan ganda, jawaban singkat, dan uraian. Tes literasi Matematika mengukur kemampuan siswa untuk menggunakan pengetahuan dan keterampilan matematika dalam penyelesaian berbagai jenis persoalan dan masalah yang berhubungan dengan matematika. Materi pertanyaan pada tes dirumuskan dalam konteks personal, societal, scientific, dan occupational. Level kognitif yang diukur ada 6 level. Untuk membedakan Level 1 hingga level 6 diwujudkan dalam rumusan dan konteks pertanyaan. Rumusan pertanyaan di mulai dari paling sederhana hingga paling kompleks (Level 6). Tes kemampuan disusun dalam beberapa paket atau seri yang mengukur materi dan jumlah sama pada setiap konten.

Kuesioner siswa memberikan informasi mengenai diri siswa yang terdiri dari 6 bagian. Bagian A tentang diri siswa; Bagian B tentang keluarga dan keadaan rumah siswa; Bagian C tentang belajar matematika; Bagian D tentang pengalaman matematika siswa; Bagian E tentang sekolah siswa; dan Bagian $\mathrm{F}$ tentang pengalaman-pengalaman menyelesaikan masalah. Penelitian ini fokus pada bagian $A$ sebagai jati diri siswa, dan Bagian B sebagai lingkungan sosial budaya. Kedua bagian dianggap dapat memberi gambaran yang memengaruhi prestasi siswa peserta PISA 2012. Variabel jati diri siswa terdiri atas pertanyaan kuesioner nomor 1 ) Kelas yang sedang ditempuh; 2) Jenjang pendidikan yang ditempuh; 3) Jenis kelamin; 4) Belajar di Taman Kanakkanak (TK); 5) Umur masuk kelas 1 SD; 6) Pernah tinggal kelas; 7) Terlambat datang ke sekolah; 8) Membolos sekolah; 9) Tidak hadir pada beberapa mata pelajaran. Variabel lingkungan sosial budaya meliputi pertanyaan 10) Tinggal serumah dengan siapa; 11) Pekerjaan utama ibu; 12) Tugas ibu dalam menjalankan pekerjaan utama; 13) Pendidikan tertinggi ibu; 14) Kualifikasi yang dimiliki ibu; 15) Status pekerjaan ibu sekarang; 16) Pekerjaan utama ayah; 17) Tugas ayah dalam melakukan pekerjaan utama; 18) Pendidikan tertinggi ayah; 19) Kualifikasi yang dimiliki ayah; 20) Status pekerjaan ayah sekarang; 21) Bahasa yang digunakan di rumah; 22) Barangbarang yang ada di rumah; 23) Benda-benda yang ada di rumah; 24) Jumlah buku yang ada di rumah.

\section{HASIL DAN PEMBAHASAN}

Dalam pembahasan variabel atau jati diri yang berpengaruh pada prestasi siswa peserta survei PISA 2012 adalah jenis kelamin, mengikuti pendidikan TK, usia masuk sekolah, mengulang di kelas, membolos, atau tidak hadir di kelas.

Jumlah total peserta Survei PISA Indonesia pada tahun 2012 berjumlah 5.622 siswa yang terdiri dari 2.860 siswa perempuan $(50,9 \%)$ dan 2.762 siswa laki-laki $(49,1 \%)$. Capaian laki-laki sebesar 377 dan siswa perempuan sebesar 374 serta rata-rata 375. Capaian tertinggi menurut jenis kelamin adalah di Shanghai China, yaitu 613 dan terendah adalah Peru, yaitu 368. Capaian laki-laki di OECD lebih tinggi daripada perempuan. Kemampuan laki-laki secara ratarata tertinggi adalah Austria, sedangkan kemampuan perempuan tertinggi adalah Yordania.

Siswa peserta survei berasal dari kelas 7 sampai dengan kelas 12 dan capaian literasi matematika tampak pada Gambar 2.

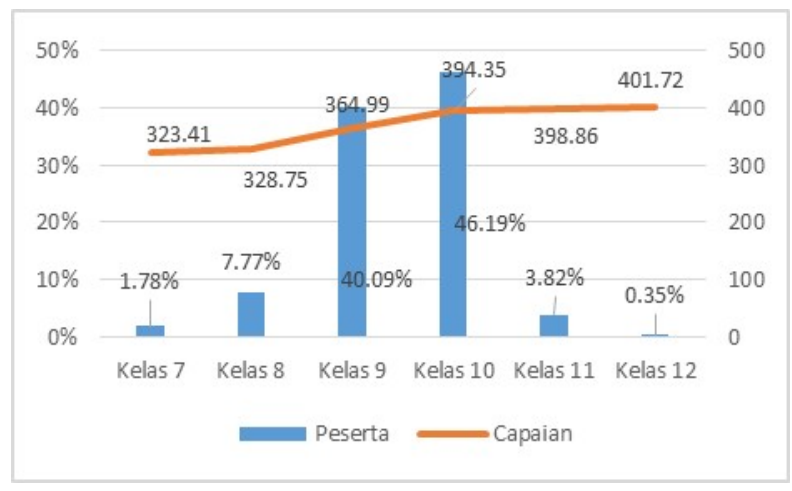

Gambar 2. Capaian Literasi Berdasarkan Kelas Siswa Peserta PISA 2012 
Peserta PISA seperti tampak pada Gambar 2 menunjukkan sebagian besar berasal dari kelas $9(40,09 \%)$ dan kelas $10(46,16 \%)$, serta siswa kelas 8 , kelas 11 , kelas 7 , dan kelas 12 . Data ini menunjukkan kecepatan dalam pembelajaran tinggi sekitar $4,17 \%$ yaitu kelas 11 dan kelas 12 serta relatif lambat sekitar 9,55\% yaitu peserta kelas 7 dan kelas 8 . Sekolah asal sekolah peserta survei adalah SMP 39,6\% (2.224 siswa); MTs 10,1\% (567 siswa); SMA 25,8\% (1.453 siswa); MA 5,5\% (311 siswa); dan SMK 19,0\% (1.067 siswa). Sebagian besar sekolah asal peserta adalah dari sekolah umum (SMP, SMA, SMK) 84,4\% dan sekolah keagamaan (MTs, MA) 15,6\%. Komposisi tersebut menggambarkan keadaan persekolahan yang ada sebab sekolah umum lebih banyak dibandingkan sekolah keagamaan.

Capaian literasi matematika menurut kelas seperti terlihat pada Gambar 2 menunjukkan adanya tren meningkat dari kelas terendah (7) hingga kelas tertinggi (12) dalam konteks umur siswa 15 tahun. Hal itu terjadi karena semakin tinggi kelas maka materi pengetahuan matematika sudah lebih banyak yang dikuasainya dan sudah menyelesaikan pendidikan wajib belajar. Capaian jenjang SMP/MTs adalah 357 (kelas 7-9) dan SMA/MA/SMK adalah 394 (kelas 10-12). Hal ini menunjukkan bahwa semakin tinggi jenjang pendidikan, semakin tinggi capaian literasi matematika. Indonesia menentukan peserta siswa adalah dari SMP/MTs karena siswa berusia 15 tahun lebih banyak pada jenjang tersebut. Sementara itu, Jepang menentukan siswa dari kelas 10 dan hasilnya adalah 563. Hal itu terjadi karena peserta sudah menyelesaikan pendidikan wajib belajar 9 tahun. Sedangkan Vietnam $80 \%$ peserta berasal dari SMA dan $20 \%$ berasal dari SMP dengan capaian 511.

Pada Gambar 3 tampak peserta PISA yang tidak pernah mengikuti pendidikan di TK dan pernah mengikuti pendidikan TK. Peserta yang mengikuti pendidikan TK adalah 54\%. Dari peserta yang mengikuti pendidikan TK ada yang berlangsung satu tahun sebanyak 31\% (1.733

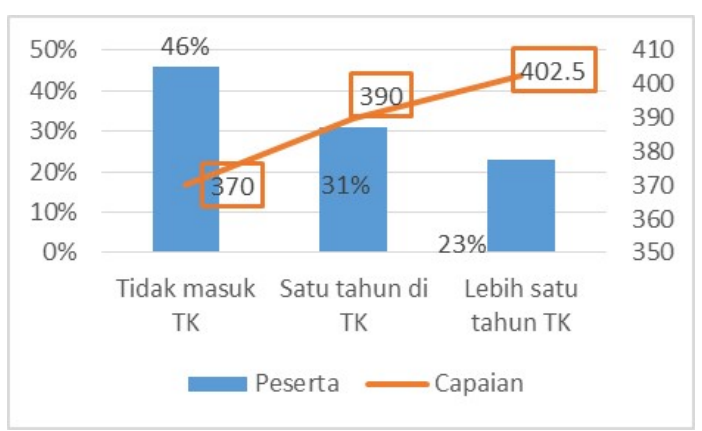

Gambar 3. Peserta PISA Mengikuti Pendidikan TK dan Capaian Literasi Matematika

siswa) dan lebih satu tahun sebanyak 23\% (1.279 siswa), sedang yang tidak masuk pendidikan TK sebanyak 46\% (2.567 siswa). Deskripsi tersebut menunjukkan bahwa peserta PISA sebagian besar telah mengikuti pendidikan. Artinya, siswa yang sudah mengikuti pendidikan lebih siap untuk menerima pendidikan lanjutan.

Capaian literasi cenderung meningkat dari siswa tidak mengikuti pendidikan TK yaitu 370, siswa yang mengikuti pendidikan TK 1 tahun atau kurang dari satu tahun capaiannya 390, dan siswa yang mengikuti pendidikan TK lebih dari 1 tahun capaiannya 402,5. Jepang 99,1\% pesertanya mendapatkan pendidikan TK dan capaian 563. Sementara itu, Turki 29\% pesertanya mendapatkan pendidikan TK dengan nilai capaian 448. Dengan demikian, peserta yang mengikuti pendidikan TK memiliki prestasi literasi matematika yang tinggi sehingga perlu dipertimbangkan untuk siswa sekolah dasar disyaratkan untuk mengikuti pendidikan TK.

Usia peserta survei ketika memasuki kelas 1 SD atau MI adalah berkisar usia 5-8 tahun, seperti tampak pada Gambar 4.

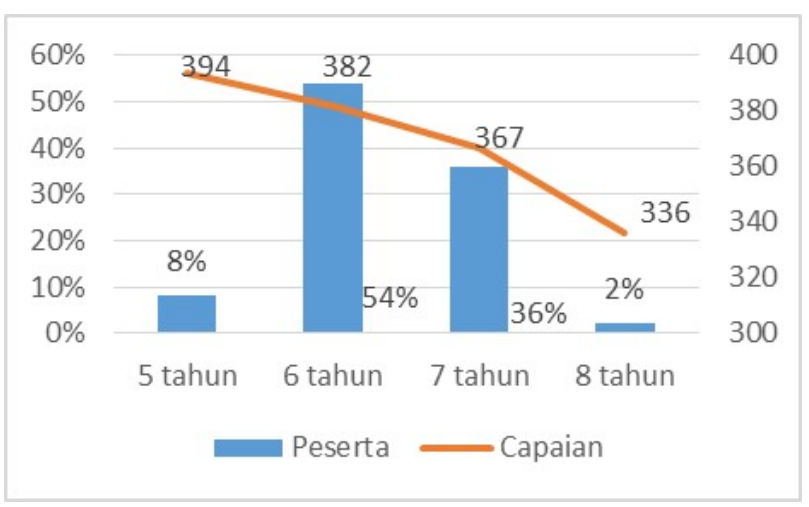

Gambar 4. Usia Masuk Kelas 1 
Gambar 4 menunjukkan 54\% peserta PISA 2012 berusia 6 tahun memasuki SD atau MI, berusia 7 tahun sebanyak 36\%, dan sisanya masuk SD atau MI pada usia 5 tahun atau 8 tahun dengan frekuensi kecil. Dalam peraturan perundangan disebutkan bahwa siswa masuk SD/MI berusia 7 tahun dan tampak dalam Gambar 4 bahwa sebagian besar masuk sekolah berusia 6 tahun dan jumlah tersebut sama dengan peserta yang mengikuti pendidikan TK sebelum masuk SD/MI.

Capaian peserta berusia 5 tahun lebih tinggi daripada usia di atasnya. Anak yang berusia 5 tahun sudah masuk sekolah menunjukkan motivasi orang tua terhadap pendidikan yang tinggi dan berasal dari keluarga yang tingat kesejahteraan yang juga tinggi. Kondisi keluarga yang sejahtera menyebabkan mereka segera memasukkan anak ke sekolah dan mereka mengawasi anak dalam belajar. Anak yang masuk sekolah berusia 8 tahun atau 7 tahun menunjukkan perhatian keluarga terhadap pendidikan anak yang kurang.

Data dalam Gambar 4 menunjukkan bahwa aksesibilitas untuk masuk SD/MI relatif sukar bagi peserta yang berusia 8 tahun. Penelitian Perdana (2015) menyatakan aksesibilitas sekolah dipengaruhi oleh jenis kelamin, wilayah tempat tinggal, latar belakang pendidikan orang tua, jarak ke sekolah, usia perkawinan orang tua, pendapatan per kapita orang tua, dan jumlah anggota rumah tangga. Dari faktor tersebut yang berkaitan dengan penelitian ini adalah tingkat pendidikan orang tua dan jumlah anggota keluarga. Tingkat pendidikan orang tua (ayah) yang relatif tinggi atau tamat SMA hingga sarjana sebesar $43 \%$ dan jumlah anggota dalam keluarga dengan ayah ibu, saudara, kakek nenek relatif tinggi. Kedua faktor ini turut mendorong siswa untuk segera masuk sekolah.

Gambar 5 menunjukkan peserta PISA 2012 ada yang mengulang pada jenjang SD/MI, SMP/

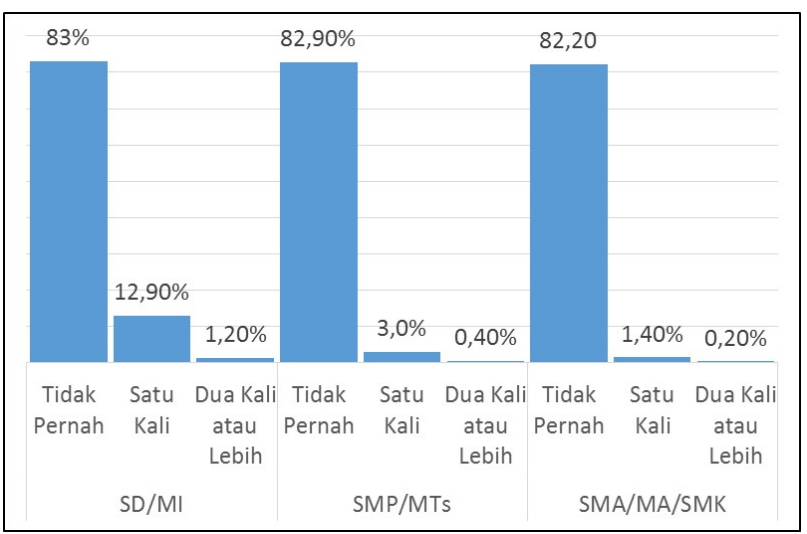

Gambar 5. Pernah Tinggal Kelas

MTs, dan SMA/MA/SMK dengan frekuensi kecil dan sebagian peserta tidak memberikan respon sehingga data tidak mencapai 100\%. Peserta yang banyak mengulang satu kali atau lebih pada jenjang SD/MI sebesar 14,1\% (790 siswa), jenjang SMP/MTs sebesar 3,9\% (221 siswa), dan SMA/MA/SMK sebesar 1,6\% (87 siswa). Sedangkan peserta paling tinggi tidak pernah mengulang SD/MI sebanyak $83 \%$ (4.668 siswa), SMP/MTs 82,9\% (4.660 siswa), dan SMA/MA/ SMK 82,2\% (2.373 siswa).

Capaian peserta tidak pernah mengulang atau tinggal kelas adalah 382 dan pernah mengulang adalah 341. Sedangkan negara tertinggi yang tidak pernah mengulang adalah Macao (China) yaitu 565 dan pernah mengulang tertinggi adalah Korea Selatan dengan capaian 530.

Informasi pada Gambar 4 menunjukkan bahwa Indonesia sudah melaksanakan wajib belajar sejak tahun 1984 tetapi masih ada peserta didik yang tinggal di SD/MI. Hal itu berarti wajib belajar di Indonesia merupakan kewajiban pemerintah untuk menyediakan sarana belajar untuk peserta didik bukan wajib belajar yang mengharuskan peserta didik naik kelas otomatis.

Informasi keterlambatan siswa datang ke sekolah dua minggu terakhir sebelum survei dilaksanakan dapat dilihat pada Gambar 6 . 


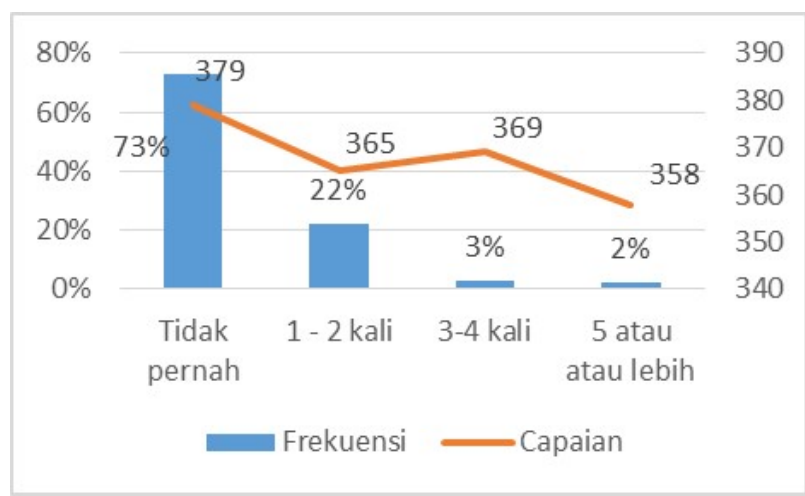

Gambar 6. Terlambat Datang di Sekolah

Pada Gambar 6 menunjukkan siswa yang tidak pernah terlambat sebanyak $73 \%$, pernah terlambat satu sampai dua kali $22 \%$, terlambat tiga sampai lima kali (5\%). Hal ini berarti jam pembelajaran pada satuan pendidikan dapat dilakukan secara tepat waktu. Capaian peserta tidak pernah terlambat adalah 379 , satu sampai dua kali 365, tiga sampai empat kali 369, dan lima kali atau lebih 358. Hal ini menunjukkan bahwa semakin sering terlambat, capaian semakin rendah. Capaian tertinggi tidak terlambat adalah Hong Kong China 569 dan paling sering terlambat tertinggi adalah Jerman 488.

Kedisipilnan peserta PISA 2012 relatif tinggi (73\%). Peserta yang tidak masuk sekolah dalam dua minggu terakhir sebelum pelaksanaan survei tampak pada Gambar 7.

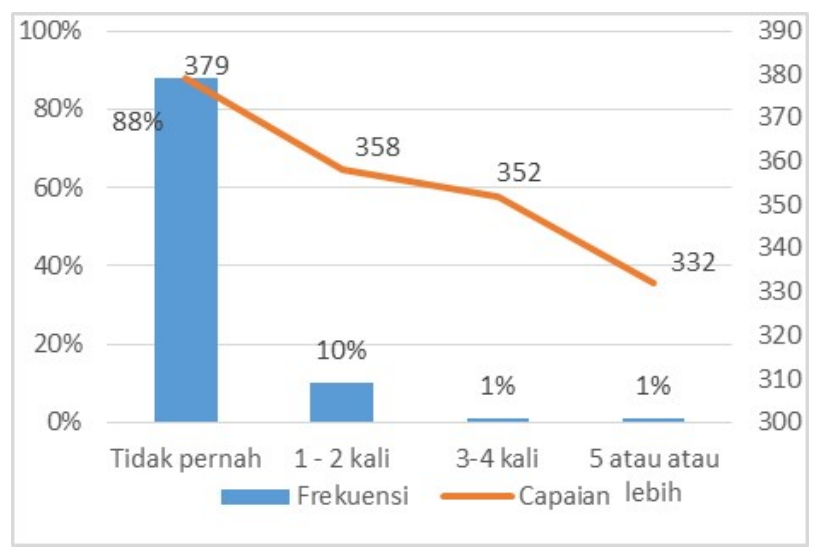

Gambar 7. Peserta Membolos

Pada Gambar 7 tampak sebagian besar siswa (88\%) tidak membolos sekolah pada dua minggu terakhir sebelum pengambilan data, $10 \%$ siswa membolos satu atau dua kali, dan $1 \%$ membolos tiga hingga empat kali membolos, dan $1 \%$ lima kali lebih membolos. Tidak ada informasi mengapa mereka sampai membolos sekolah. Capaian peserta tidak pernah membolos adalah 379 (4.922 siswa=87,54\%), satu sampai dua kali membolos 358 (559 siswa=9,94\%), tiga sampai empat kali membolos 352 (73 siswa= $1,30 \%)$, dan lima kali atau lebih membolos 332 (32 siswa $=0,57 \%$ ). Data tersebut menunjukkan bahwa semakin sering membolos maka capaian nilai peserta semakin rendah. Negara dengan siswa paling rajin dengan angka membolos 2,7\% adalah Belanda dengan capaian 523, sedangkan negara dengan tingkat membolos tertinggi adalah Turki $(54,2 \%)$ dengan capaian 448.

Frekuensi peserta PISA 2012 yang tidak hadir pada beberapa mata pelajaran dalam dua pekan sebelum pelaksanaan survei tampak pada Gambar 8.

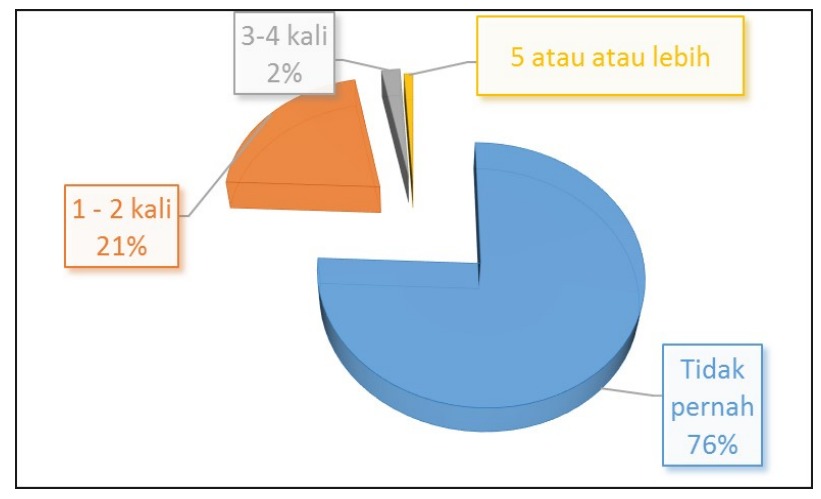

Gambar 8. Peserta Tidak Hadir

Gambar 8 menunjukkan ketidakhadiran siswa dalam beberapa mata pelajaran dalam tempo dua minggu sebelum pengambilan data. Siswa yang tidak pernah menghadiri pelajaran sebanyak $76 \%$, satu sampai dua kali tidak hadir $21 \%$, tiga sampai empat kali tidak hadir $2 \%$, dan lima kali atau lebih tidak hadir 1\%. Sesuai dengan data tersebut, peserta PISA 2012 lebih sering tidak masuk pada beberapa mata pelajaran dibandingkan dengan pelajaran matematika. Negara yang siswanya tidak pernah hadir adalah Shanghai China sebanyak 99,3\% dan yang paling sering tidak masuk sekolah adalah Yordania sebanyak $36,6 \%$. 
Faktor lingkungan sosial budaya siswa yang memengaruhi peserta didik dalam penelitian adalah peserta PISA 2012 berkaitan dengan kondisi rumah tinggal, tugas utama, tingkat pendidikan, pekerjaan ayah ibu, bahasa yang digunakan, dan barang-barang yang dimiliki di rumah. Keluarga merupakan tumpuan dari setiap anak, lingkungan yang pertama dari anak, serta dari keluargalah anak menerima pendidikan yang diperlukan dalam menunjang perkembangan anak. Informasi tentang peranan keluarga terhadap prestasi peserta PISA 2012 tampak pada Gambar 9.

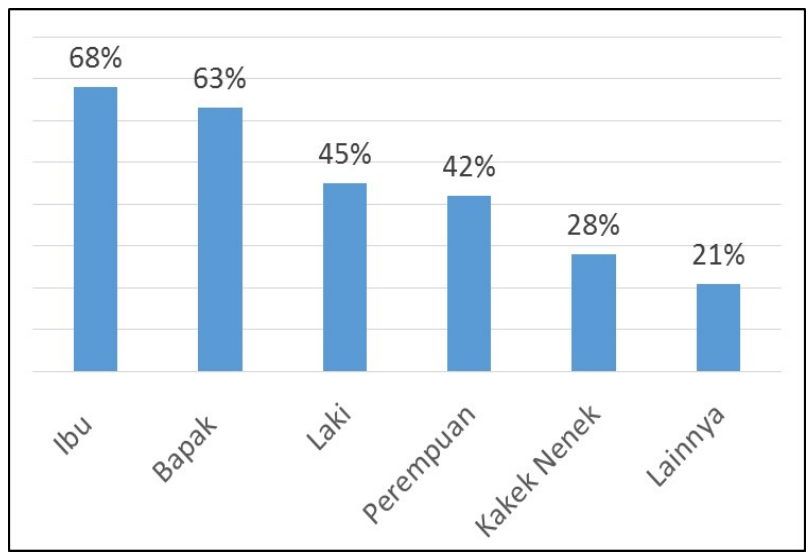

Gambar 9. Teman Tinggal di Rumah

Pada Gambar 9 tampak siswa yang tinggal bersama ibu $68 \%$ lebih banyak daripada siswa yang tinggal bersama ayah yaitu $63 \%$. Sesuai data dapat diartikan bahwa sekitar 5\% atau lebih siswa tinggal bersama Ibu bahkan bisa lebih besar walaupun ada kemungkinan peserta hanya tinggal bersama Ayah. Siswa ada yang tinggal bersama saudara laki-laki dan saudara perempuan dengan persentase yang hampir seimbang yaitu antara $42 \%-45 \%$. Sementara ada $28 \%$ siswa yang tinggal bersama kakek dan nenek. Dengan demikian, peserta PISA hidup dalam keluarga yang terdiri dari ayah ibu, saudara laki atau perempuan serta kakek nenek. Capaian peserta PISA 2012 berdasarkan faktor atau kondisi rumah tinggal peserta adalah 362. Prestasi tersebut tidak lepas dari peran dan fungsi orang tua karena dalam keluarga ditanamkan sendi-sendi dasar pendidikan yang
Tabel 2. Pendidikan Tertinggi Ibu dan Ayah

\begin{tabular}{clcc}
\hline No. & \multicolumn{1}{c}{ Tamat } & Ibu & Ayah \\
\hline 1. & S3 & $2,24 \%$ & $2,79 \%$ \\
2. & S1, S2 & $7,6 \%$ & $9,75 \%$ \\
3. & D1,D2,D3,D4 & $4,89 \%$ & $5,87 \%$ \\
4. & SMA/MA/SMK & $35,41 \%$ & $41,75 \%$ \\
5. & SMP/MTs & $19,46 \%$ & $19,19 \%$ \\
6. & SD/MI/Tidak Tamat & $30,4 \%$ & $20,65 \%$ \\
\hline
\end{tabular}

Sumber: OECD, 2013a

memengaruhi kepribadian anak. Capaian negara peserta Studi PISA 2012 secara rata-rata siswa tinggal bersama ayah ibu 503 sedangkan yang tinggal bersama dengan orang tua tunggal (single parents) 487.

Tabel 2 menggambarkan rata-rata pendidikan tertinggi yang diselesaikan oleh orangtua. Ibu yang berpendidikan SMA/MA/SMK sebanyak $35,41 \%$ dan ayah $41,75 \%$. Sedangkan ibu yang berpendidikan SD/MI/tidak tamat adalah 30,40\% dan Ayah 20,65\%. Ibu yang menyelesaikan jenjang pendidikan S3 adalah 2,24\% dan Ayah $2,79 \%$. Dari uraian tersebut tampak pendidikan tertinggi yang diselesaikan adalah S3 sedang terendah adalah tidak tamat SD. Perbandingan pendidikan yang diselesaikan secara rata-rata relatif sama hanya berbeda dalam jumlah yaitu SMA/MA/SMK, SD/MI/Tidak Tamat, SMP/MTs, S1,S2, D1,D2,D3, D4, dan S3. Pendidikan orangtua memengaruhi pencapaian hasil belajar siswa. Orangtua yang berpendidikan formal lebih tinggi umumnya lebih banyak berbeda dalam pola berpikir, beraspirasi, dan berpandangan, jika dibandingkan dengan orang tua yang tidak berpendidikan formal. Hasil ini sesuai dengan hasil penelitian Reskia, Herlina, \& Zulnuraini (2016) yang mengatakan bahwa tingkat pendidikan orangtua akan memengaruhi prestasi anak melalui cara yang mereka berikan dalam membimbing atau mengarahkan anak belajar di rumah.

Prestasi atau capaian peserta PISA 2012 sesuai jenjang pendidikan yang diselesaikan Ibu Ayah tampak pada Gambar 10. 


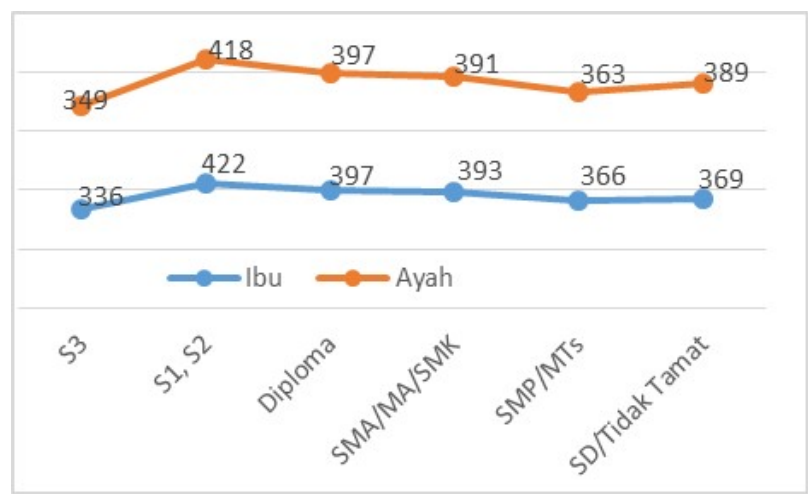

Gambar 10. Capaian Literasi Berdasarkan Tingkat Pendidikan Ibu Ayah

Gambar 10 menunjukkan capaian peserta PISA 2012 sesuai dengan jenjang pendidikan antara Ibu dengan Ayah. Secara rata-rata capaian peserta PISA 2012 pada semua jenjang yang diselesaikan Ibu dan Ayah relatif sama. Dalam gambar tampak bahwa semakin tinggi jenjang pendidikan Ibu dengan Ayah semakin meningkat capaian peserta PISA 2012. Namun, terjadi anomali pada jenjang S3 yang cenderung rendah. Apakah ini terjadi karena kesibukan Ibu Ayah dengan pendidikan S3 sehingga mengurangi perhatian pada anaknya karena fokus pada pekerjaan atau kesibukannya. Tidak ada informasi yang dapat dijadikan pegangan.

Tempat lahir siswa peserta PISA 2012 98,8\% adalah di Indonesia termasuk orangtua mereka lahir di Indonesia baik Ibu maupun Ayah 98,30\%. Bahasa yang digunakan di rumah sebagian besar menggunakan bahasa daerah sebanyak $57,74 \%$ dan siswa yang menggunakan bahasa Indonesia di rumah sebesar $40,18 \%$ serta sebagian tidak menjawab. Capaian peserta PISA 2012 sesuai dengan bahasa yang digunakan tidak berbeda. Untuk yang menggunakan Bahasa Indonesia 376 sedang bahasa daerah 375 .

Pada Gambar 11 tampak pekerjaan Ibu dengan Ayah bekerja penuh dengan mendapat upah, bekerja paruh waktu dengan mendapat upah, tidak bekerja, tetapi sedang mencari pekerjaan, dan lainnya misalnya mengerjakan pekerjaan rumah tangga, pensiunan, dan wiraswasta. Berdasarkan kategori tersebut, rata-rata Ibu yang bekerja di sektor lainnya

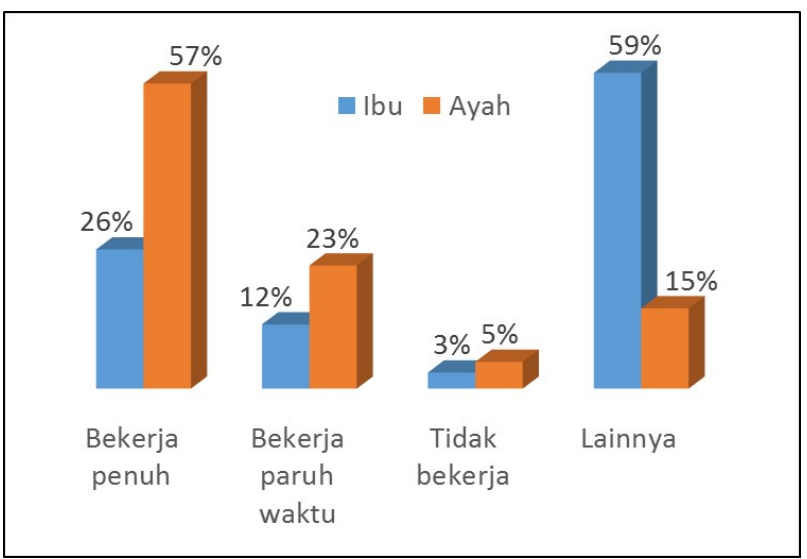

Gambar 11. Pekerjaan Ibu dan Ayah

59\%. Artinya Ibu bekerja sebagai ibu rumah tangga atau wiraswasta dan Ayah bekerja penuh 57\%. Ibu bekerja penuh 26\% dan Ayah bekerja paruh waktu $23 \%$. Sementara ibu yang tidak bekerja 3\% dan Ayah 5\%. Capaian perserta PISA 2012 dengan kondisi pekerjaan Ibu dan Ayah tampak pada Gambar 12.

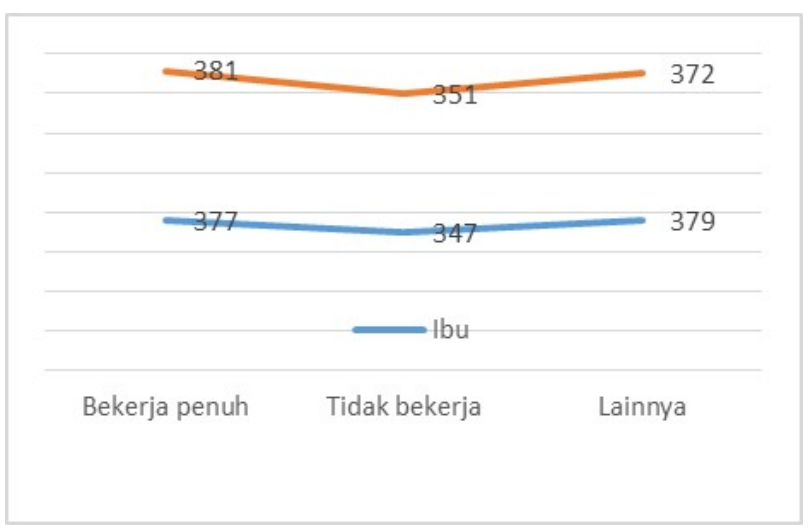

Gambar 12. Capaian Berdasarkan Pekerjaan Orang Tua

Informasi capaian peserta PISA 2012 pada setiap kategori relatif sama antara bekerja penuh, lainnya, dan tidak bekerja. Capaian secara rata-rata peserta studi PISA OECD Ibu Ayah bekerja 503 dan tidak bekerja 479, sedangkan capaian tertinggi adalah China Shanghai 638 untuk bekerja dan Singapura 582 untuk tidak bekerja. Capaian negara terendah adalah Albania 389 dan Peru untuk tidak bekerja 366.

Ibu dan Ayah yang bekerja memiliki kemampuan untuk menyediakan sarana atau 
kebutuhan pendidikan anak-anak dan sarana belajar seperti tampak dalam Tabel 2.

Berdasarkan Tabel 2 tampak fasilitas penunjang belajar yang paling banyak dimiliki siswa adalah buku yang dapat membantu mengerjakan tugas sekolah $(90,3 \%)$ dan kamus $(94,4 \%)$. Benda lain yang dimiliki sebagian besar siswa adalah meja belajar (71,8\%), kamar pribadi $(79,1 \%)$, tempat belajar yang tenang $(56,9 \%)$, DVD atau VCD $(76,9 \%)$ dan sepeda motor $(82,2 \%)$. Barang-barang lain dimiliki oleh sebagian kecil siswa antara 16,9\%-53,6\% yaitu mobil, buku rujukan teknis, perangkat lunak (software) pendidikan, sambungan internet,

Tabel 2. Fasilitas Penunjang Belajar Siswa

\begin{tabular}{|c|c|c|c|}
\hline No. & $\begin{array}{c}\text { Jenis Barang Yang } \\
\text { Dimiliki }\end{array}$ & $\mathrm{Ya}$ & Tidak \\
\hline 1. & Meja belajar & $71,8 \%$ & $28,2 \%$ \\
\hline 2. & Kamar pribadi & $79,1 \%$ & $20,9 \%$ \\
\hline 3. & $\begin{array}{l}\text { Tempat belajar } \\
\text { yang tenang }\end{array}$ & $56,9 \%$ & $43,1 \%$ \\
\hline 4. & $\begin{array}{l}\text { Komputer untuk } \\
\text { mengerjakan } \\
\text { tugas sekolah }\end{array}$ & $26,2 \%$ & $73,8 \%$ \\
\hline 5. & $\begin{array}{l}\text { Perangkat lunak } \\
\text { (software) } \\
\text { pendidikan }\end{array}$ & $19,4 \%$ & $80,6 \%$ \\
\hline 6. & $\begin{array}{l}\text { Sambungan } \\
\text { internet }\end{array}$ & $23,3 \%$ & $76,7 \%$ \\
\hline 7. & Buku sastra klasik & $21,9 \%$ & $78,1 \%$ \\
\hline 8. & $\begin{array}{l}\text { Buku-buku } \\
\text { kumpulan puisi }\end{array}$ & $37,3 \%$ & $62,7 \%$ \\
\hline 9. & $\begin{array}{l}\text { Karya seni } \\
\text { (misalnya lukisan) }\end{array}$ & $53,6 \%$ & $46,4 \%$ \\
\hline 10. & $\begin{array}{l}\text { Buku yang dapat } \\
\text { membantu } \\
\text { mengerjakan } \\
\text { tugas sekolah }\end{array}$ & $90,3 \%$ & $9,7 \%$ \\
\hline 11. & $\begin{array}{l}\text { Buku rujukan } \\
\text { teknis }\end{array}$ & $18,4 \%$ & $81,6 \%$ \\
\hline 12. & Kamus & $94,4 \%$ & $5,6 \%$ \\
\hline 13. & Mesin cuci & $29,5 \%$ & $70,5 \%$ \\
\hline 14. & $D V D$ atau $V C D$ & $76,9 \%$ & $23,1 \%$ \\
\hline 15. & Kamera digital & $27,5 \%$ & $72,5 \%$ \\
\hline 16. & Sepeda motor & $82,2 \%$ & $17,8 \%$ \\
\hline 17. & Mobil & $16,9 \%$ & $83,1 \%$ \\
\hline
\end{tabular}

Sumber: OECD, 2013a
Tabel 3. Benda-benda yang Dimiliki Keluarga Siswa di Rumah

\begin{tabular}{|c|c|c|c|c|c|}
\hline No & $\begin{array}{l}\text { Nama } \\
\text { Benda }\end{array}$ & $\begin{array}{c}\text { Tidak } \\
\text { Ada }\end{array}$ & $\begin{array}{l}\text { Ada } \\
\text { Satu }\end{array}$ & $\begin{array}{l}\text { Ada } \\
\text { Dua }\end{array}$ & $\begin{array}{c}\text { Lebih } \\
\text { dari } \\
\text { satu }\end{array}$ \\
\hline 1. & $\begin{array}{l}\text { Telepon } \\
\text { genggam/ } \\
\text { HP }\end{array}$ & $4,5 \%$ & $\begin{array}{c}23,6 \\
\%\end{array}$ & $\begin{array}{c}25,1 \\
\%\end{array}$ & $\begin{array}{c}46,8 \\
\%\end{array}$ \\
\hline 2. & Televisi & $7,3 \%$ & $\begin{array}{c}68,1 \\
\%\end{array}$ & $19 \%$ & $5,6 \%$ \\
\hline 3. & Komputer & $\begin{array}{c}73,6 \\
\%\end{array}$ & $\begin{array}{c}21,1 \\
\%\end{array}$ & $3,8 \%$ & $1,5 \%$ \\
\hline 4. & Mobil & $\begin{array}{c}84,3 \\
\%\end{array}$ & $\begin{array}{c}11,9 \\
\%\end{array}$ & $2,5 \%$ & $1,3 \%$ \\
\hline 5. & $\begin{array}{l}\text { Kamar } \\
\text { yang ada } \\
\text { kamar } \\
\text { mandi di } \\
\text { dalam } \\
\end{array}$ & $\begin{array}{c}77,9 \\
\%\end{array}$ & $\begin{array}{c}13,5 \\
\%\end{array}$ & $3,0 \%$ & $2,2 \%$ \\
\hline
\end{tabular}

Sumber: OECD, 2013a

komputer untuk mengerjakan tugas, dan kamera digital. Kepemilikan sarana tersebut meningkatkan prestasi dan capaian siswa seperti tampak dalam Tabel 2

Selain fasilitas belajar, keluarga siswa juga memiliki benda seperti pada Tabel 3. Tampak pada Tabel 3 sebagian besar keluarga siswa tidak memiliki komputer $(73,6 \%)$, mobil $(84,3 \%)$, dan kamar yang terdapat kamar mandi di dalamnya (77,9\%). Hal ini menunjukkan bahwa sebagian besar siswa peserta studi PISA berasal dari kalangan ekonomi menengah ke bawah.

Sebagian besar siswa $(68,1 \%)$ memiliki televisi di rumah. Kondisi ini menunjukkan bahwa televisi sudah merupakan kebutuhan dalam keluarga untuk mendapatkan infomasi dari luar. Hanya sebagian kecil siswa yang tidak memiliki televisi $(7,3 \%)$ dan telepon genggam $(4,5 \%)$.

Pada Gambar 12 tampak kepemilikan bukubuku (ilmu pengetahuan) di luar buku pelajaran, majalah dan surat kabar pada keluarga siswa. Dari seluruh siswa peserta studi PISA yang berjumlah 5622, hanya 6\% yang memiliki 1-200 buku di rumah, hanya $3 \%$ yang memiliki buku di atas 200 buku, dan di atas 500 buku. Sebagian besar siswa (37\%) hanya memiliki 11-25 buku di rumah, dan 26\% memiliki buku antara 26100 buku. Kondisi ini menunjukkan bahwa buku 


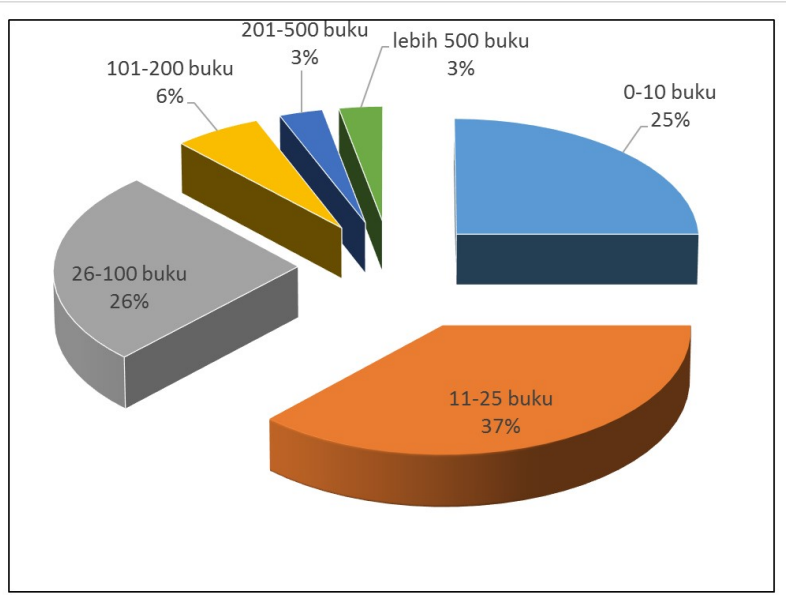

Gambar 12. Jumlah Buku di Rumah

belum menjadi hal yang penting dalam keluarga Indonesia.

Faktor dominan yang memengaruhi prestasi siswa PISA 2012 dari faktor jati diri siswa adalah kedudukan di sekolah yaitu capaian peserta dari SMP/MTs, 357 lebih rendah dari SMA/MA/SMK, 394. Hal ini menunjukkan siswa SMA/MA/SMK sudah mengetahui lebih banyak pengetahuan dan keterampilan matematika. Pendidikan TK yang ditempuh peserta berperan untuk menentukan prestasi siswa. Capaian siswa yang mengikuti pendidikan TK 1 tahun atau kurang adalah 390, lebih dari 1 tahun adalah 402,5, sedangkan yang tidak mengikuti pendidikan TK adalah 353. Kondisi ini menunjukkan bahwa pembelajaran atau permainan pada pendidikan TK turut berperan dalam kesiapan siswa untuk mengikuti pembelajaran atau pengetahuan matematika. Kedisiplinan peserta masuk sekolah atau sering membolos turut memengaruhi prestasi. Capaian peserta yang tidak pernah membolos adalah 379, sedang yang membolos satu sampai dua kali adalah 358, tiga sampai empat kali membolos adalah 352, dan lima kali atau lebih membolos adalah 332. Semakin sering membolos maka capaian dalam matematika semakin rendah. Negara yang siswanya paling rajin yaitu Shanghai China 99,3\% dan yang paling sering tidak masuk sekolah adalah Yordania 36,6\%.

Faktor lingkungan sosial budaya siswa yang dominan memengaruhi prestasi siswa adalah jumlah anggota keluarga dengan capaian 362 . Sedangkan capaian siswa yang tinggal bersama Ibu Ayah 503 sedangkan yang bersama orangtua tunggal (single parents) adalah 487. Pendidikan Ibu Ayah memengaruhi prestasi siswa. Capaian siswa dengan orangtua menyelesaikan pendidikan SD/MI/Tidak Tamat, Ibu 369 dan Ayah 389, pendidikan SMP/MTs, Ibu 366 dan Ayah 363, SMA/MA/SMK, Ibu 393 dan Ayah 391, pendidikan D1,D2,D3,D4, Ibu 397 dan Ayah 397, pendidikan S1,S2, Ibu 422 dan Ayah 418, pendidikan S3 Ibu 336 dan Ayah 349.

Capaian siswa karena pengaruh bahasa yang digunakan dalam rumah tidak ada, Bahasa Indonesia 376 dan bahasa daerah 375 . Pengaruh pekerjaan orangtua terhadap capaian siswa dari ibu yang bekerja penuh adalah 377 dan Ayah 381, ibu yang tidak bekerja 347 dan Ayah 351, dan pekerjaan ibu dan ayah lainnya masing-masing 379 dan 372.

Tabel 4. Korelasi Prestasi Matematika dengan Status Sosial Ekonomi-Budaya Keluarga

\begin{tabular}{|c|c|c|c|}
\hline & & $\begin{array}{l}\text { Plausible value } 1 \text { in } \\
\text { mathematics }\end{array}$ & $\begin{array}{c}\text { Index of economic, social } \\
\text { and status }\end{array}$ \\
\hline \multirow{3}{*}{$\begin{array}{l}\text { Plausible value } 1 \text { in } \\
\text { mathematics }\end{array}$} & Pearson Correlation & 1 &, $284^{* *}$ \\
\hline & Sig. (2-tailed) & &, 000 \\
\hline & $\mathrm{N}$ & 5622 & 5606 \\
\hline \multirow{3}{*}{$\begin{array}{l}\text { Index of economic, social } \\
\text { and cultural status }\end{array}$} & Pearson Correlation & $284^{* *}$ & 1 \\
\hline & Sig. (2-tailed) & ,000 & \\
\hline & $\mathrm{N}$ & 5606 & 5606 \\
\hline
\end{tabular}

**. Correlation is significant at the 0.01 level (2-tailed).

Sumber: Hasil pengolahan data 
Untuk menguji hubungan prestasi belajar matematika dengan status sosial ekonomibudaya keluarga peserta berupa pendidikan ayah ibu, pekerjaan, bahasa, rumah tinggal, kebiasaan, dan pemilikan rumah, kamar mandi, mobil, diolah dengan menggunakan metode statistik, Hierarchical Linear Modeling (HLM) yang tepat digunakan pada data bertingkat (multilevel data). Hasil pengolahan tampak pada Tabel 4, korelasi 0,284 dengan $P$-Value/Sig sama dengan $0,00<0,05$. Hal ini menunjukkan terdapat hubungan antara prestasi belajar matematika siswa dengan lingkungan sosial, dan budaya peserta PISA. Kondisi lingkungan sosial ekonomi-budaya sangat berpengaruh terhadap prestasi siswa PISA 2012.

Pengolahan hubungan prestasi matematika dengan kepemilikan atau ketersediaan fasilitas pendidikan di rumah seperti yang digambarkan dalam Tabel 2 dan Tabel 3. Hasil pengolahan dengan HLM tampak pada Tabel 5. Informasi dalam Tabel 5 menunjukkan korelasi antara prestasi matematika dengan kepemilikan komputer baik hardware maupun software di rumah sebesar 0,303. Hal ini menunjukkan kepemilikan komputer di rumah dapat membantu peserta didik dalam pem-belajaran (khususnya dalam mata pelajaran matematika). Semakin banyak penggunaan komputer di dunia pembelajaran, akan membawa keuntungan bagi siswa dan guru. Siswa menjadi lebih mudah belajar karena kebanyakan siswa lebih senang praktek dibandingkan dengan teori. Dalam membuat tugas siswa lebih mudah mencari sumber bahan karena memiliki koneksi internet. Buku-buku sumber yang berkaitan dengan matematika mendorong siswa untuk belajar dan didukung dengan ketersediaan komputer meningkatkan prestasi siswa.

\section{SIMPULAN DAN SARAN}

\section{Simpulan}

Hasil penelitian menunjukkan bahwa faktor jenis kelamin tidak memengaruhi capaian literasi siswa Indonesia peserta studi PISA 2012 bahkan relatif sama. Capaian literasi siswa peserta SMP/ MTs lebih rendah daripada capaian siswa SMA/ MA/SMK. Hal ini disebabkan siswa SMA/SMK telah menyelesaikan pendidikan wajib belajar 9 tahun.

Lingkungan sosial budaya yang memengaruhi prestasi siswa peserta PISA 2012 adalah kondisi rumah tingggal artinya peserta tinggal dengan siapa dan tingkat pendidikan orangtua. Sedangkan penggunaan bahasa dalam rumah tidak berpengaruh pada prestasi siswa. Orang tua yang bekerja penuh turut berpengaruh pada capaian siswa. Kondisi sosial yang melekat pada orangtua berhubungan secara signifikan dengan prestasi siswa. Orangtua yang bekerja diharapkan dapat menyediakan sarana buku, komputer, dan sarana lain untuk mendukung

Tabel 5. Korelasi Prestasi Matematika dengan Komputer dan Buku

\begin{tabular}{llrr}
\hline & & $\begin{array}{c}\text { Plausible value } \\
1 \text { in } \\
\text { mathematics }\end{array}$ & ICT resources \\
& & \multicolumn{1}{c}{, $303^{* *}$} \\
Plausible value 1 in & Pearson Correlation & 5622 &, 000 \\
mathematics & Sig. (2-tailed) &, $303^{* *}$ & 5495 \\
\hline & $\mathrm{N}$ &, 000 & 1 \\
ICT resources & Pearson Correlation & 5495 & 5495 \\
& Sig. (2-tailed) & & \\
\hline
\end{tabular}

**. Correlation is significant at the 0.01 level (2-tailed).

Sumber: Hasil pengolahan data 
aktivitas belajar siswa. Kondisi pemilikan sarana belajar, buku, dan komputer juga menunjukkan bahwa ada hubungan yang signifikan antara kepemilikan terhadap prestasi belajar.

Faktor-faktor dominan yang memengaruhi prestasi siswa Indonesia peserta PISA 2012 yaitu faktor jati diri dan faktor sosial budaya. Faktor jati diri terdiri atas jenjang pendidikan, pendidikan TK, dan kedisiplinan masuk sekolah.

\section{Saran}

Berdasarkan hasil pembahasan, siswa peserta studi PISA di masa datang sebaiknya berasal dari dari SMA sederajat dan sebelum masuk jenjang pendidikanSD/MI disyaratkan untuk mengikuti pendidikan TK. Sekolah hendaknya mengendalikan kedisiplinan siswa agar jumlah yang membolos sedikit. Selain itu, orangtua hendaknya memotivasi siswa untuk belajar lebih aktif. Peran orangtua dan sekolah juga perlu ditingkatkan dalam hal penyediaan sarana buku teks di rumah atau sekolah untuk membantu siswa mencari informasi atau materi pengetahuan yang berhubungan dengan matematika. Sarana lain yang perlu ditingkatkan adalah penyediaan sarana komputer dengan softwere yang berkaitan dengan matematika untuk digunakan dalam proses pembelajaran sehingga dapat meningkatkan prestasi atau capaian siswa khususnya untuk pengetahuan matematika.

\section{PUSTAKA ACUAN}

Darlington, E. \& Jessica B. 2016. The Mathematics Needs of Prospective Architecture Undergradutes. Research Matters. Cambridge: University of Cambridge Local Examinations Syndicate.

Fahmi. 2011. Perbandingan Nilai Ujian Nasional dan Ujian Sekolah Mata Pelajaran Matematika SMA Program IPA Tahun Pelajaran 2010/2011. Jurnal Pendidikan dan Kebudayaan, 17(6), 674-680.

Fathurrohman, M. 2015. Paradigma Pembelajaran Kurikulum 2013 Strategi Alternatif Pembelajaran di Era Global. Yogyakarta: Kalimedia.

Mahdiansyah \& Rahmawati. 2014. Literasi Matematika Jenjang Jenjang Pendidikan Menengah: Analisis Menggunakan Desain Tes Internasional dengan Konteks Indonesia. Jurnal Pendidikan dan Kebudayaan, 20(4), 452-469.

Nurdin, S. \& Adriantoni. 2016. Kurikulum dan Pembelajaran. Jakarta: Raja Grafindo Persada.

OECD. 2013a. PISA 2012 Results: What Student Know and Can Do. Student Performance in Reading, Mathematics and Science Volume I, III, IV. Paris: OECD Publishing.

OECD. 2013b. PISA 2012 Assessment and Analytical Framework: Mathematics, Reading, Science, Problem Solving and Financial Literacy. Paris: OECD Publishing.

Ozga, J. 2012. Assessing PISA. European Educational Research Journal, 11(2), 166-171.

Pakpahan, R. 2012. Model Alternatif Ujian Akhir. Jurnal Pendidikan dan Kebudayaan 18(2), 121131.

Paneo, H. 2004. Pengaruh Umpan Balik Evaluasi Formatif dan Kepribadian Siswa Terhadap Hasil Belajar Matematika. Disertasi. Jakarta: Universitas Negeri Jakarta.

Panjaitan, M.O. 2014. Implementasi Pendekatan Belajar Aktif di Sekolah Menengah Atas. Jurnal Pendidikan dan Kebudayaan 20(1) 44-58.

Perdana, N.S. 2015. Faktor-faktor yang Berpengaruh terhadap Aksesibilitas Memeroleh Pendidikan untuk Anak-anak Indonesia. Jurnal Pendidikan dan Kebudayaan 21(3), 279297. 
Raharjo, S. B. 2014. Kontribusi Delapan Standar Nasional Pendidikan terhadap Pencapaian Prestasi Belajar. Jurnal Pendidikan dan Kebudayaan 20(4), 470-482.

Rahman, A. 2008. Pengaruh Tes Formatif dan Kemandirian Belajar Terhadap Hasil Belajar Ekonomi Siswa SMA DKI Jakarta. Disertasi. Jakarta: Universitas Negeri Jakarta.

Reskia, S., Herlina, \& Zulnuraini. 2016. Pengaruh Tingkat Pendidikan Orang Tua Terhadap Prestasi Belajar Di SDN Inpres 1 Birobuli. Elementry School of Education E-Journal.

Sellar, S. \& Bob, L. 2014. The OECD and the Expansion of PISA: New Global Modes of Governance in Education. British Educational Research Journal, 40(6), 917-936.

Slameto. 2010. Belajar dan Faktor-Faktor Yang Mempengaruhinya. Jakarta: Rineka Cipta.

Tilaar, H.A.R. 2015. Pedagogik Teoritis Untuk Indonesia. Jakarta: Kompas.

Triwiyanto, T. 2014. Pengantar Pendidikan. Jakarta Bumi Aksara.

Willms, J.D. 2011. Student Engagement: A Leadership Priority. In Conversation. III(2), 1-12, http://edu.gov.on.ca/eng/policyfunding/leadership/Summer2011.pdf diakses 18 November 2016. 
